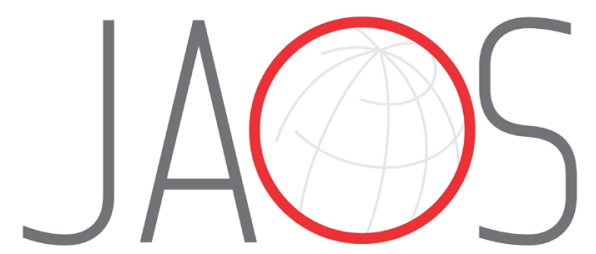

\title{
Effect of periodontal treatment in patients with periodontitis and diabetes: systematic review and meta-analysis
}

\section{Abstract}

Mauricio BAEZA ${ }^{1,2}$

Alicia MORALES ${ }^{1,3}$

Carlos CISTERNA ${ }^{1}$

Franco CAVALLA ${ }^{1}$

Gisela JARA ${ }^{3}$

Yuri ISAMITT ${ }^{4}$

Paulina $\mathrm{PINO}^{3}$ Jorge GAMONAL ${ }^{1,3}$ iD
Submitted: May 7, 2019 Modification: August 29, 2019 Accepted: September 19, 2019

Corresponding address: Jorge Gamona Facultad de Odontología - Universidad de Chile. Avenida Olivos, 943 - Comuna de Independencia Santiago - Chile Phone: 0056-2-9781700 e-mail: jgamonal@odontologia.uchile.cl
The evidence is inconclusive regarding the effect of periodontal treatment on glycemic control and systemic inflammation in patients with type 2 diabetes (T2D) and periodontitis Objective: To evaluate the effect of scaling and root planing (SRP) on the metabolic control and systemic inflammation of patients with type 2 diabetes (T2D). Methodology: A literature search was conducted using the MEDLINE database via PubMed and the Cochrane Central Register of Controlled Trials, from their oldest records up to July 2018. Only randomized clinical trials (RCT) were considered eligible for evaluating the effect of periodontal treatment on markers of metabolic control [glycated hemoglobin $(\mathrm{HbA} 1 \mathrm{C})$ ] and systemic inflammation [C-reactive protein (CRP)] in patients with T2D. The quality of the studies was evaluated using the Cochrane Collaboration risk assessment tool. Meta-analyses were performed for HbA1C and CRP using random effects models. The size of the overall intervention effect was estimated by calculating the weighted average of the differences in means (DM) between the groups in each study. Heterogeneity was assessed using the Q-statistic method $\left(\mathrm{x}^{2}\right.$ and $\left.\mathrm{I}^{2}\right)$. The level of significance was established at $p<0.05$. Results: Nine RCT were included. SRP was effective in reducing HbA1c $[D M=0.56(0.36-0.75) ; \mathrm{p}<0.01]$ and CRP $[D M=1.89(1.70-2.08) ; p<0.01]$. No heterogeneity was detected $\left(\mathrm{I}^{2}=0 \%\right.$, $\mathrm{p}>0.05)$. Conclusions: SRP has an impact on metabolic control and reduction of systemic inflammation of patients with T2D.

Keywords: Periodontitis. Cardiovascular diseases. Diabetes mellitus.

'Universidad de Chile, Facultad de Odontología, Departamento de Odontología Conservadora, Santiago, Chile.

2Universidad de Chile, Facultad de Medicina, Escuela de Salud Pública, Santiago, Chile.

${ }^{3}$ Universidad de Chile, Facultad de Odontología, Centro de Epidemiología y Vigilancia de las

Enfermedades Orales (CEVEO), Santiago, Chile.

${ }^{4}$ Universidad de Chile, Facultad de Odontología, Departamento de Prótesis, Santiago, Chile. 


\section{Introduction}

Type 2 diabetes (T2D) and periodontitis are closely related noncommunicable diseases (NCDs) that present a high prevalence in the world, seriously compromising the quality of life of the affected population. ${ }^{1,2}$ The number of people with diabetes has increased from 108 million in 1980 to 422 million in 2014 and is considerably higher in middle and lower income countries. ${ }^{3}$ Diabetes has become a leading cause of death and disability in the region of the Americas, and if current trends continue, the burden of the disease will increase substantially over the next two decades. ${ }^{4}$ In Mexico and in the majority of the countries of Central and South America and the Spanish-speaking Caribbean, diabetes prevalence has been reported between $8 \%$ and $10 \% .^{4}$

In Chile, according to the last National Health Survey, ${ }^{5}$ the prevalence of diabetes is $12.3 \%$. In turn, the prevalence of periodontal destruction in Chile is greater than $85 \%$ in people over 35 years of age. ${ }^{6}$ Despite the heterogeneity in the operational definition of the disease, most studies show that the prevalence of periodontitis in Latin America is high. ${ }^{7}$

Although there are no epidemiological studies of simultaneity of both pathologies, a meta-analysis showed that people with T2D have twice the risk of developing periodontitis compared with those without diabetes. ${ }^{8}$ These data show that almost all patients with T2D have periodontitis simultaneously.

T2D is characterized by an altered hyperglycemic metabolic state and is associated with a decrease in life expectancy of ten years and with long-term complications that may include cardiovascular disease, diabetic retinopathy, and kidney failure. ${ }^{9}$ Periodontitis, however, is currently considered a noncommunicable chronic inflammatory pathology of infectious etiology. The bidirectional pathogenic association between both diseases has been extensively documented. ${ }^{10}$ Diabetic patients are more susceptible to severe periodontitis and it may increase the risk of poor glycemic control. ${ }^{11}$ The effect of periodontitis on diabetes may be related to the penetration of the host tissues by bacteria or their degradation products into the systemic circulation. Activation of an exaggerated systemic inflammatory response to subgingival bacteria leads to an acute phase protein burst and systemically elevated levels of proinflammatory mediators which facilitate insulin resistance. ${ }^{12,13}$ Metabolic dysregulation in diabetes as a result of prolonged exposure to chronic hyperglycemia can lead to the glycosylation of proteins and lipids, called advanced glycation end- products (AGEs). They can explain many of the sequelae of diabetes, such as microvascular complications. Local periodontal tissue destruction may be a consequence of an exaggerated monocytic inflammatory response induced by AGEs accumulation and result in exaggerated secretion of local and systemic mediators leading to severe periodontitis. ${ }^{14}$ The binding of AGEs to monocyte receptors induces production of interleukin- 1 (IL-1), IL-6, insulin- like growth factor-1, tumor necrosis factor- alfa (TNF- $\alpha$ ) and platelet- derived growth factor. ${ }^{15}$ Those are some factors that initiate and maintain an inflammatory response and regulate the transcription of human Acute Phase Reactants, like C-reactive protein (CRP). CRP is a sensitive inflammatory marker and an independent predictor of cardiovascular diseases. ${ }^{16}$

The poor glycemic control of diabetic patients, defined as glycated hemoglobin (HbA1c) values $>7 \%$, is associated with microvascular and macrovascular complications. ${ }^{17}$ Macrovascular complications also known as cardiovascular diseases (CVD) are an important cause of morbidity and mortality among individuals with T2D. Patients with T2D have an increased risk of premature atherosclerotic plaque development, which is the central pathogenic mechanism of CVD. To a great extent, the endothelial dysfunction present in patients with poor glycemic control is associated with the high production of CRP as a result of systemic inflammation caused by AGEs. ${ }^{18}$ The role of systemic inflammation and, consequently, of high levels of CRP has been described in all phases of atherosclerosis, from the onset and build-up of plaque to rupture. From the biological point of view, CRP participates in the atherogenic process, and its concentration predicts cardiovascular events. ${ }^{19}$ The cardiovascular effects of CRP have been described mainly through endothelial dysfunction by reducing nitric oxide levels. Endothelial dysfunction facilitates the activation, migration, and lodging of leukocytes inside the tunica intima. This phenomenon contributes to the formation of vascular lesions that are the basis of the development of atherosclerosis. When lowdensity lipoproteins reach a certain concentration threshold in the blood, they penetrate the interior of the arterial wall, where they are modified by oxidation processes. CRP binds to these lipoproteins (both 
native and oxidized) and facilitates phagocytosis and internalization mediated by the macrophages of the intima, promoting the formation of foam cells (macrophages with large amounts of oxidized lipids inside). The accumulation of foam cells is determinant for the pathogenic evolution of an arterial plaque, making it more prone to erosion or rupture and releasing its thrombogenic content. This prothrombotic property also adds to the ability of CRP to induce the production of tissue factor (initiator of the coagulation cascade) by activated macrophages. ${ }^{20}$ Also, CRP levels are elevated in patients with periodontitis ${ }^{21.22}$ and their CRP levels may go down after periodontal therapy. ${ }^{21}$

Studies conducted in the last decade indicate that the control of chronic inflammatory processes caused by periodontitis may constitute a new approach in reducing the risk of cardiovascular complications in patients with T2D. Based on this concept, clinical trials have been designed to determine the possible beneficial effects of conventional periodontal treatment, consisting of the mechanical removal of the subgingival biofilm by means of scaling and root planing (SRP) in diabetic patients. Despite the variability, the results of these studies have been mostly favorable. However, systematic reviews have been limited to the analysis of $\mathrm{HbA} 1 \mathrm{C}$ as an end point measure, ${ }^{23}$ without considering other variables such as those associated with systemic inflammation that can provide us with a better approach to reducing the risk of diabetic complications, especially those related to CVD. The objective of this systematic review was to answer the following question: Can conventional periodontal treatment compared with the absence of periodontal treatment improve metabolic control and reduce systemic inflammation in patients with periodontitis and T2D?

\section{Methodology}

\section{Protocol}

The protocol was designed in accordance with the Cochrane standards for systematic reviews. The search criteria complied with the Preferred Reporting Items for Systematic reviews and Meta-Analysis Protocols (PRISMA) guidelines.

\section{Criteria for the inclusion of studies}

Type of studies: The study design was a randomized controlled clinical trial, as it is the most appropriate type of study to answer the research question since it presents a lower risk of systematic errors and greater control over potential confounding variables, constituting the best scientific evidence to support the efficacy of therapeutic interventions.

Type of participants and inclusion/exclusion criteria: Participants with a diagnosis of T2D and periodontitis were included. Other inclusion criteria were the following: (1) Participants with 3 or more months of post intervention follow-up and (2) HbA1c and CRP evaluation at the beginning and end of the follow-up.

Types of periodontal interventions: Periodontal interventions were based on different conventional treatments, including oral hygiene instruction and SRP (with or without flap surgery). Periodontal interventions were compared with the passive option (without periodontal treatment).

Outcomes:

Primary: $\mathrm{HbA} 1 \mathrm{C}$ and CRP

Secondary: Occurrence of adverse events related to periodontal treatment.

\section{Search strategy}

We searched the following databases from their oldest records until July 10, 2018: 1) MEDLINE through PubMed and 2) Cochrane Central Register of Controlled Trials (CENTRAL). The articles in both databases are only available in English. The search terms (MeSH terms) were "periodontitis" OR "periodontal" AND (therapy OR treatment) AND (diabetes OR metabolic control OR glycemic control OR glycated hemoglobin OR HbA1c OR systemic inflammation OR C-reactive protein OR hsCRP).

\section{Study eligibility and data extraction}

All retrieved articles were evaluated by two independent reviewers (MB and AM). Inter reviewer reliability in the study selection process was determined by the Cohen $k$ test, assuming an acceptable threshold value of $0.61 .24,25$ Disagreements were resolved by consensus. If a disagreement persisted, the judgment of a third reviewer (JG) was considered final. Irrelevant records (abstracts not available, bibliographic reviews, descriptive studies, animal studies) were excluded, and the full texts of potentially relevant studies were examined to answer the question of interest. The relevant studies that met the inclusion criteria were analyzed, with the following data extracted: 1) demographic characteristics (age, sample size, country where the study was conducted), 2) definition 
of disease, 3) control measures of T2D, 4) periodontal intervention, 5) outcome variable (HbA1c and/or CRP) and their initial values, 6) follow-up period and final values, and 7) results (average change in HBA1c and/ or CRP in each group).

\section{Quality of the evidence}

The evaluation of the quality of the selected studies was carried out using the Cochrane Collaboration tool to assess the risk of bias. ${ }^{26}$

\section{Diagnostic evaluation}

T2D was diagnosed according to the criteria of the World Health Organization, ${ }^{27}$ defined as fasting plasma glucose $>126 \mathrm{mg} / \mathrm{dl}$ and/or impaired oral glucose tolerance test at $2 \mathrm{~h}$. Due to the heterogeneity of the criteria and the definitions of periodontitis, any diagnosis of periodontitis was accepted as defined by the authors.

\section{Statistical analysis}

The data extracted from the studies were analyzed using RevMan 5.3 software (The Nordic Cochrane Centre, The Cochrane Collaboration, Copenhagen, Denmark). The corresponding meta-analyses were carried out to determine the effect of the periodontal intervention on the variables $\mathrm{HbA} 1 \mathrm{C}$ and CRP, comparing the group that received the periodontal treatment (intervention group) with the group that did not receive periodontal treatment (control group). The effect size was estimated and reported as the difference between the intervention group and the control group in the means of the changes occurring in the levels of $\mathrm{HbA} 1 \mathrm{c}$ and CRP between the start and the end of the follow-up, and the 95\% confidence interval (CI) was calculated. Due to the expected heterogeneity between the studies, a random effects model was used. ${ }^{28}$ The combined overall effect (weighted average) was considered significant if $p<0.05$. The forest plots for each meta-analysis present raw data (means, standard deviations, and sample sizes), point estimates (shown as blocks) and CIs (shown as lines) of the effect of each study, the total number of participants per group, the general average effect of the model ( $Z$ statistic), and the weight percentage for each study. Heterogeneity was assessed using the Q-statistic method based on $\mathrm{X}^{2}$ and the $\mathrm{I}^{2}$ measurement. The publication bias of the articles was investigated for each outcome variable (HbA1c and CRP) by visual inspection of asymmetries in the funnel plot. ${ }^{29}$

\section{Results}

\section{Search results}

A total of 402 articles were retrieved using databases from two online sources (MEDLINE and Cochrane Library). After the elimination of duplicates $(n=53), 349$ titles and abstracts were reviewed, 292 of which were excluded because they did not meet the basic inclusion criteria (designs without intervention, reviews, or patients with DT1) (inter- reviewer agreement, $\mathrm{k}=0.76)$. Fifty-seven complete articles were evaluated in more detail to determine their eligibility, nine of which met the criteria for inclusion in the systematic review and meta-analysis (inter reviewer agreement, $\mathrm{k}=0.88$ ). The flow chart following the PRISMA criteria and model of the complete search and inclusion process of the studies is illustrated in Figure 1.

\section{Description of the studies}

The main characteristics of the included studies $(n=9)$ are presented in Figure 2. All the included studies $^{30-37}$ were randomized clinical trials with a control group without periodontal intervention. To control for the possible placebo effect, oral hygiene instruction (IHO) was administered in two studies; ${ }^{31-36}$ supragingival scaling was performed in another study in the control group; ${ }^{34}$ and no type of treatment was reported for the control group in the remaining studies. The intervention in all the studies was a conventional periodontal treatment with nonsurgical (SRP), except for the study by Chen, et al. ${ }^{30}$ (2012), which included surgical debridement at 3 months. The definition used for the diagnosis of periodontitis varied widely among the studies. Periodontitis was diagnosed in four studies according to the criteria of the American Academy of Periodontology (AAP), ${ }^{30,34,35,37}$ in one study ${ }^{36}$ according to the Eke criteria, ${ }^{38}$ in another study according to unspecified criteria, ${ }^{33}$ and in the remaining three studies according to different severity criteria. ${ }^{32,37,39}$ Regarding smoking, one study excluded smokers, ${ }^{37}$ another did not report whether smokers were included as a selection criterion, ${ }^{39}$ and the rest of the studies included smokers, with a balance between the groups after randomization. In relation to $T 2 D$, all the studies reported the diagnostic criteria following the WHO guidelines, with a variable onset date. In turn, all reported metabolic control measures for the treatment of T2D, except one, ${ }^{39}$ and all reported that there were 
no changes in the T2D treatment scheme during follow-up, except one that did not report these data. ${ }^{35}$ The initial values, final values, and changes (delta) in HbA1c and/or CRP in each group of each study are presented in Figure 1.

The main reasons to exclude 49 studies were "inadequate control group" ( $n=25), 40-64$ "inadequate intervention and/ or inadequate case definition" $(n=17),{ }^{65-81}$ "inadequate evaluation and or high risk of bias" $(n=6)^{82-87}$ (Figure 7).

\section{Risk of bias in the included studies}

To determine the validity of the included studies, a tool developed by the Cochrane Collaboration was used to assess the risk of bias in clinical trials. ${ }^{26}$ Using this tool, the reviewer evaluated the risk of bias of the selected studies using the following parameters: random sequence generation, allocation concealment, blinding of participants and personnel, analysis intention (blinding of outcome assessment), incomplete outcome data, selective reporting (selection of the reported results), and other types of bias not considered previously (e.g., design bias, contamination bias). All articles adequately reported random sequence generation, allocation concealment, blinding of outcome assessment, incomplete outcome data and selective reporting. In six articles in which the control group did not undergo any procedure, it was not possible to blind the personnel and the participants; only in one study $^{34}$ was it possible to ensure the blinding of the participants, and blinding in the other two studies was unclear. ${ }^{31,69}$ Other unspecified types of bias were also considered as associated with the lack of information regarding control measures and possible changes in the management of $\mathrm{T}^{2} \mathrm{D}^{39}$ or interventions performed by a general dentist and nonspecialist, ${ }^{36}$ and there were less clear situations such as those related to the contamination of the results (contamination bias) due to the effect of procedures in the control group (debridement and/or IHO). The general scheme of the risk of bias is presented in Figure 3, and a detailed summary by study is provided in Figure 4.

\section{Effect of the intervention}

Primary HbA1c Outcomes: The results of the metaanalysis indicate a significant reduction in \% $\mathrm{HbA} 1 \mathrm{c}$ from the beginning to the end of the follow-up in the intervention group [differences in means $(D M)=0.56$,

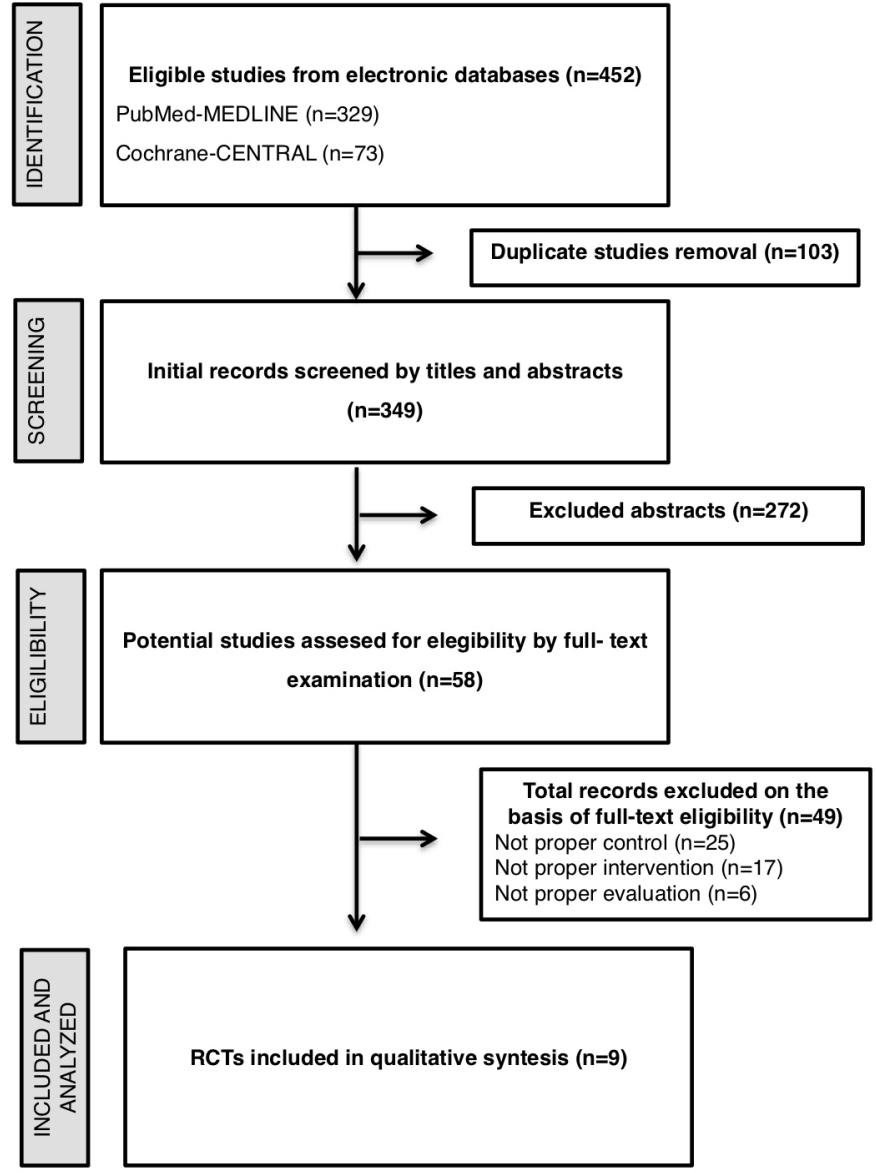

Figure 2- Selection of studies for systematic review 


\begin{tabular}{|c|c|c|c|c|c|c|c|c|c|}
\hline $\begin{array}{c}\text { Authorl } \\
\text { year }\end{array}$ & Country & $\mathbf{N}$ & Age (years) & $\begin{array}{c}\text { Case definition (PD } \\
\text { - DT2) }\end{array}$ & $\begin{array}{c}\mathrm{DT2} \\
\text { treatment }\end{array}$ & $\begin{array}{l}\text { Intervention v/s } \\
\text { Control }\end{array}$ & $\begin{array}{c}\text { Inicial } \\
\text { measures } \\
\text { (HbA1c and/or } \\
\text { CRP) }\end{array}$ & $\begin{array}{c}\text { Follow-up; } \\
\text { Final measures }\end{array}$ & $\begin{array}{c}\text { Results } \\
\Delta \mathrm{HbA1c}(\%) \\
\text { and/ or CRP } \\
\text { (mg/l) }\end{array}$ \\
\hline $\begin{array}{l}\text { Kiran, et al. } .^{33} \\
\quad(2005)\end{array}$ & Turkey & $\begin{array}{l}\mathrm{I}=22 \\
\mathrm{C}=22\end{array}$ & $\begin{array}{l}\mathrm{I}=55.9 \pm 11.2 \\
\mathrm{C}=52.8 \pm 12.2\end{array}$ & $\begin{array}{l}\text { 1.PD=Periodontitis (not } \\
\text { especificated) 2.DT2 } \\
(\mathrm{WHO})=\mathrm{HbA} 1 \mathrm{c} \quad 6-8 \%\end{array}$ & $\begin{array}{l}\text { Without } \\
\text { changes in } \\
\text { medication } \\
\text { nor diet }\end{array}$ & $\begin{array}{c}\mathrm{I}=\mathrm{SRP} \\
\mathrm{C}=\text { No treatment }\end{array}$ & $\begin{array}{c}\text { HbA1c: } \\
\mathrm{l}=7.31 \pm 0.74 \\
\mathrm{C}=7.00 \pm 0.72\end{array}$ & $\begin{array}{c}3 \text { months; } \\
I=6.51 \pm 0.80 \\
C=7.31 \pm 2.08\end{array}$ & $\begin{array}{c}\Delta \mathrm{HbA} 1 \mathrm{c}: \\
\mathrm{I}=0.86 \pm 0.77 \\
\mathrm{C}=-0.31 \pm 1.82\end{array}$ \\
\hline $\begin{array}{l}\text { Singh, et al. }{ }^{39} \\
(2008)\end{array}$ & India & $\begin{array}{l}\mathrm{I}=15 \\
\mathrm{C}=15\end{array}$ & Not reported & $\begin{array}{c}\text { 1.PD }=\text { Moderate } \\
\text { to severe } \\
\text { periodontitis }(\geq 30 \% \\
\text { periodontal pocket) } \\
\text { 2.DT2 }(\mathrm{WHO})=\text { without } \\
\text { complications }\end{array}$ & $\begin{array}{l}\text { Not } \\
\text { reported }\end{array}$ & $\begin{array}{c}\mathrm{I}=\mathrm{SRP} \text { in } \\
2 \text { sessions } \\
\mathrm{C}=\text { No treatment }\end{array}$ & $\begin{array}{l}\text { HbA1c: } \\
\mathrm{l}=7.9 \pm 0.7 \\
\mathrm{C}=8.0 \pm 0.7\end{array}$ & $\begin{array}{l}3 \text { months; } \\
I=7.3 \pm 0.6 \\
C=8.2 \pm 0.74\end{array}$ & $\begin{array}{c}\Delta \mathrm{HbA1c:} \quad \mathrm{I}= \\
0.6 \pm 0.65 \\
\mathrm{C}=-0.2 \pm 0.72\end{array}$ \\
\hline $\begin{array}{l}\text { Koromantzos, } \\
\text { et al. }{ }^{34}(2011)\end{array}$ & Greece & $\begin{array}{l}I=30 \\
C=30\end{array}$ & $\begin{array}{l}\mathrm{I}=59.62 \pm 7.95 \\
\mathrm{C}=59.42 \pm 9.8\end{array}$ & $\begin{array}{c}\text { 1. PD= } \\
\text { Periodontitis (AAP) } \\
\text { 2.DT2 (WHO) } \\
\text { 2a.HbA1C (7\%- } \\
\text { 10\%). 2b. Duration } \\
\text { DT2 (years): } \\
\text { I=7.76 } \pm 4.33 \\
\text { C=7.84 } \pm 6.80\end{array}$ & $\begin{array}{l}\text { Without } \\
\text { changes. } \\
\text { Glucose } \\
\text { lowering } \\
\text { drugs and } \\
\text { insulin }\end{array}$ & $\begin{array}{c}\mathrm{I}=\mathrm{SRP} \text { in } \\
2 \text { sessions } \\
\mathrm{C}=\text { Supragingival } \\
\text { debdridment }\end{array}$ & $\begin{array}{c}\text { HbA1c: } \\
l=7.87 \pm 0.74 \\
C=7.59 \pm 0.66\end{array}$ & $\begin{array}{c}6 \text { months; } \\
I=7.16 \pm 0.69 \\
C=7.46 \pm 0.72\end{array}$ & $\begin{array}{c}\Delta \mathrm{HbA} 1 \mathrm{c}: \\
\mathrm{l}=0.72 \pm 0.93 \\
\mathrm{C}=0.13 \pm 0.46\end{array}$ \\
\hline $\begin{array}{l}\text { Koromantzos, } \\
\text { et al. }{ }^{35}(2012)\end{array}$ & Greece & $\begin{array}{l}I=30 \\
C=30\end{array}$ & $\begin{array}{l}\mathrm{I}=59.62 \pm 7.95 \\
\mathrm{C}=59.42 \pm 9.8\end{array}$ & $\begin{array}{c}\text { 1.PD = Severe } \\
\text { periodontitis(AAP) } \\
\text { 2.DT2 }(\mathrm{WHO})=\mathrm{HbA} 1 \mathrm{c} \\
7 \%-10 \%\end{array}$ & $\begin{array}{l}\text { Glucose } \\
\text { lowering } \\
\text { drugs and } \\
\text { insulin }\end{array}$ & $\begin{array}{c}\mathrm{I}=\mathrm{SRP} \text { in } 2 \\
\text { sessions } \quad \mathrm{C}=\mathrm{No} \\
\text { treatment }\end{array}$ & $\begin{array}{c}\text { CRP: } \\
\mathrm{I}=\log 0.41 \pm 0.19 \\
\mathrm{C}=\log 0.29 \pm 0.25\end{array}$ & $\begin{array}{c}6 \text { months; } \\
\text { I=log0.08 } \pm 0.26 \\
C=\log 0.37 \pm 0.19\end{array}$ & $\begin{array}{c}\Delta \mathrm{CRP}: \\
\mathrm{l}=1.26 \pm 052 \\
\mathrm{C}=-0.57 \pm 0.49\end{array}$ \\
\hline $\begin{array}{l}\text { Chen, et al. }{ }^{30} \\
\text { (2012) }\end{array}$ & China & $\begin{array}{c}\text { (a) } \\
I=42 \\
b) I=43 \\
C=41\end{array}$ & $\begin{array}{l}\text { (a) } 59.86 \pm 9.4 \\
\text { (b) } 57.91 \pm 11.3 \\
C=63.2 \pm 8.51\end{array}$ & $\begin{array}{l}\text { 1. } \mathrm{PD}=\text { Periodontitis } \\
\text { (AAP):Clinical } \\
\text { attachement loss } \\
>1 \mathrm{~mm} \text { and }>16 \text { teeth } \\
2 . \mathrm{DT} 2 \text { (WHO). } \\
\text { Duration DT2 (years): } \\
\text { (a) } 8.69 \pm 5.25 \\
\text { (b) } 6.93 \pm 4.31 \\
\text { C: } 9.56 \pm 6.02\end{array}$ & $\begin{array}{l}\text { Without } \\
\text { changes. } \\
\text { Diet, } \\
\text { glucose } \\
\text { lowering } \\
\text { drugs and } \\
\text { insulin }\end{array}$ & $\begin{array}{c}\text { (a)l=SPR } \\
\text { and surgical } \\
\text { debdridment at } \\
3 \text { months post } \\
\text { initial treatment. } \\
\text { (b)I=SPR and } \\
\text { supragingival } \\
\text { debdridment at } \\
3 \text { months post } \\
\text { initial treatment } \\
\mathrm{C}=\text { No treatment }\end{array}$ & $\begin{array}{c}\text { HbA1c } \\
\text { and CRP: } \\
\text { (a) HbA1c: } \\
\text { I=7.31 } 1.23 \\
\mathrm{C}=7.25 \pm 1.49 \\
\text { (a) CRP: } \\
\text { I=3.21 } \pm 4.45 \\
\mathrm{C}=2.81 \pm 4.05 \\
\text { (b) } \mathrm{HbA} 1 \mathrm{c}: \\
\mathrm{I}=7.29 \pm 1.55 \\
\mathrm{C}=7.25 \pm 1.49 \\
\text { (b) } \mathrm{CRP}: \\
\mathrm{I}=3.09 \pm 4.64 \\
\mathrm{C}=2.81 \pm 4.05\end{array}$ & $\begin{array}{c}6 \text { months; } \\
\text { (a) HbA1c: } \\
\text { I=7.09 } \pm 1.34 \\
\mathrm{C}=7.38 \pm 1.57 \\
\text { (a) CRP: } \\
\text { I=1.58 } \pm 1.31 \\
\mathrm{C}=3.16 \pm 5.45 \\
\text { (b) HbA1c: } \\
\text { I=6.87 } \pm 1.12 \\
\mathrm{C}=7.38 \pm 1.57 \\
\text { (b) } \mathrm{CRP}: \\
\mathrm{I}=1.53 \pm 1.27 \\
\mathrm{C}=3.16 \pm 5.45\end{array}$ & $\begin{array}{c}\Delta \mathrm{HbA} 1 \mathrm{c} \\
\text { and CRP: } \\
\text { (a) HbA1c: I= } \\
0.22 \pm 1.28 \\
\mathrm{C}=-0.13 \pm 1.53 \\
\text { (a) CRP: I= } \\
1.63 \pm 0.71 \\
\mathrm{C}=-0.35 \pm 1.06 \\
\text { (b) } \mathrm{HbA} 1 \mathrm{c}: \\
\mathrm{I}=0.42 \pm 1.38 \\
\mathrm{C}=-0.13 \pm 1.53 \\
\text { (b) CRP: } \\
\text { I=1.56 } \pm 0.73 \\
\mathrm{C}=-0.35 \pm 1.06\end{array}$ \\
\hline $\begin{array}{l}\text { Moeintaghavi, } \\
\text { et al. }{ }^{37}(2012)\end{array}$ & Iran & $\begin{array}{l}\mathrm{I}=22 \\
\mathrm{C}=18\end{array}$ & $50.29 \pm 3$ & $\begin{array}{l}\text { 1.PD = Mild to } \\
\text { moderate periodontitis } \\
\text { (AAP) } 2 . \mathrm{DT} 2 \text { (WHO): } \\
\text { HbA1c }>7 \% \text { without } \\
\text { complications }\end{array}$ & $\begin{array}{l}\text { Without } \\
\text { changes. } \\
\text { Medication } \\
\text { without } \\
\text { insulin }\end{array}$ & $\begin{array}{c}\mathrm{I}=\mathrm{SRP} \\
\mathrm{C}=\mathrm{No} \text { treatment }\end{array}$ & $\begin{array}{c}\text { HbA1c: } \\
\mathrm{I}=8.15 \pm 1.18 \\
\mathrm{C}=8.72 \pm 2.22\end{array}$ & $\begin{array}{c}3 \text { months; } \\
I=7.41 \pm 1.18 \\
C=8.97 \pm 1.82\end{array}$ & $\begin{array}{c}\Delta \mathrm{HbA} 1 \mathrm{c}: \\
\mathrm{I}=0.74 \pm 1.18 \\
\mathrm{C}=-0.25 \pm 2.04\end{array}$ \\
\hline $\begin{array}{l}\text { Gay, et al. }{ }^{31} \\
(2014)\end{array}$ & USA & $\begin{array}{l}\mathrm{I}=66 \\
\mathrm{C}=60\end{array}$ & $\begin{array}{l}\mathrm{I}=51.5 \pm 9.0 \\
\mathrm{C}=54 \pm 10.2\end{array}$ & $\begin{array}{l}\text { 1. } \mathrm{PD}=\text { Localized or } \\
\text { generalized severe } \\
\text { periodontitis (AAP). } \\
\begin{array}{l}\text { 2. DT2 }(\mathrm{WHO}) \\
=\mathrm{HbA} 1 \mathrm{c}>5.7\end{array}\end{array}$ & $\begin{array}{l}\text { Without } \\
\text { changes. } \\
\text { Glucose } \\
\text { lowering } \\
\text { drugs }\end{array}$ & $\begin{array}{c}\mathrm{I}=\mathrm{SRP} \\
\mathrm{C}=\text { Oral hygiene } \\
\text { instruction }\end{array}$ & $\begin{array}{l}\mathrm{HbA} 1 \mathrm{c}: \\
\mathrm{I}=9.0 \pm 2.3 \\
\mathrm{C}=8.4 \pm 2.0\end{array}$ & $\begin{array}{l}4 \text { months; } \\
I=8.4 \pm 1.9 \\
C=8.1 \pm 1.8\end{array}$ & $\begin{array}{l}\Delta \mathrm{HbA} 1 \mathrm{c}: \\
\mathrm{l}=0.6 \pm 2.1 \\
\mathrm{C}=0.3 \pm 1.7\end{array}$ \\
\hline $\begin{array}{l}\text { Kaur, et al. }{ }^{32} \\
(2015)\end{array}$ & India & $\begin{array}{l}\mathrm{I}=50 \\
\mathrm{C}=50\end{array}$ & $\begin{array}{c}\mathrm{I}=51.8 \pm 5.8 \\
\mathrm{C}=52.9 \pm 6.03\end{array}$ & $\begin{array}{c}\text { 1.PD= Moderate } \\
\text { Periodontitis } 2 . \mathrm{DT} 2 \\
(\mathrm{WHO})=\text { Good control } \\
(\mathrm{n}=50 ; \mathrm{Hba} 1 \mathrm{c}<7 \%) \text { and } \\
\text { poor control }(n=50 ; \\
\text { HbA } 1 \mathrm{c}>7 \%)\end{array}$ & $\begin{array}{l}\text { Without } \\
\text { changes. } \\
\text { Glucose } \\
\text { lowering } \\
\text { drugs/ } \\
\text { insulin }\end{array}$ & $\begin{array}{c}\mathrm{I}=\mathrm{SRP} \\
\mathrm{C}=\mathrm{No} \text { treatment }\end{array}$ & $\begin{array}{c}\text { HbA1c: } \\
\mathrm{I}=8.17 \pm 2.49 \\
\mathrm{C}=7.87 \pm 2.56\end{array}$ & $\begin{array}{c}3 \text { months; } \\
I=7.49 \pm 1.83 \\
C=7.96 \pm 2.65\end{array}$ & $\begin{array}{c}\Delta \mathrm{HbA} 1 \mathrm{c}: \\
\mathrm{I}=0.69 \pm 0.78 \\
\mathrm{C}=-0.09 \pm 0.31\end{array}$ \\
\hline $\begin{array}{c}\text { Mizuno, et al. }{ }^{36} \\
(2017)\end{array}$ & Japan & $\begin{array}{l}\mathrm{I}=20 \\
\mathrm{C}=17\end{array}$ & $\begin{array}{c}\mathrm{I}=61.2 \pm 9.2 \\
\mathrm{C}=62.8 \pm 12.1\end{array}$ & $\begin{array}{l}\text { 1.EP=Moderate to } \\
\text { severe periodontitis } \\
(\text { Eke et al. 2012) } \\
\text { 2. DT2 }(\mathrm{WHO})= \\
\text { Duration }>2 \text { months }\end{array}$ & $\begin{array}{l}\text { Without } \\
\text { changes in } \\
\text { medication }\end{array}$ & $\begin{array}{c}\mathrm{I}=\mathrm{SRP} \\
\mathrm{C}=\text { Oral hygiene } \\
\text { instruction }\end{array}$ & $\begin{array}{l}\text { HbA1c: } \\
\mathrm{I}=7.5 \pm 1.7 \\
\mathrm{C}=7.7 \pm 1.2\end{array}$ & $\begin{array}{l}3 \text { months; } \\
\mathrm{I}=7.4 \pm 1.4 \\
\mathrm{C}=7.7 \pm 1.1\end{array}$ & $\begin{array}{l}\Delta \mathrm{HbA} 1 \mathrm{c}: \\
\mathrm{I}=0.1 \pm 1.5 \\
\mathrm{C}=0.0 \pm 0.1\end{array}$ \\
\hline
\end{tabular}

I= Intervention Group; $C=$ Control Group; PD= Periodontal Disease; DT2: Diabetes mellitus 2; (a) Intervention Group A of Chen et al. ${ }^{30}$ 2012 study; (b) Intervention Group B of Chen et al. ${ }^{30} 2012$ study; CRP: C- reactive protein; SRP=Scaling and root planing

Figure 2- Characteristics of studies included in the systematic review

$95 \%$ CI $(0.36-0.75), p<0.00001]$. In this metaanalysis, no heterogeneity was detected among the included studies $\left(\mathrm{X}^{2}=5.89, \mathrm{I}^{2}=0 \%, p=0.66\right)$ (Figure 6A).

Primary CRP Outcomes: Regarding the results of CRP levels, the meta-analysis indicated a significant reduction from the start to the end of follow-up in favor of the intervention group [DM=1.89, 95\% CI (1.70$2.08), p<0.00001]$. No heterogeneity was detected among the included studies $\left(\mathrm{x}^{2}=0.36, \mathrm{I}^{2}=0 \%, p=0.83\right)$ in this meta-analysis (Figure 6B).

Secondary Outcome: None of the included studies reported the occurrence of adverse effects or complications related to periodontal treatment.

\section{Publication biases}

Visual inspection of the funnel plot for studies included in the meta-analysis that evaluated the effect 


\begin{tabular}{|c|c|c|}
\hline Inadequate control group $(n=25)$ & $\begin{array}{l}\text { Inadequate intervention and/or } \\
\text { inadequate case definition }(n=17)\end{array}$ & $\begin{array}{c}\text { Inadequate evaluation and/or high risks } \\
\text { of bias }(n=6)\end{array}$ \\
\hline Grossi, et al. ${ }^{48}(1997)$ & Khader, et al. ${ }^{72}(2010)$ & Li, et al. ${ }^{84}(2009)$ \\
\hline Rodrigues, et al. ${ }^{57}$ (2003) & Calabrese, et al. ${ }^{65}$ (2011) & Zhang, et al. ${ }^{87}(2013)$ \\
\hline Skaleric, et al. ${ }^{60}(2004)$ & Nassar, et al..$^{74}(2011)$ & Hincapié, et al. ${ }^{83}$ (2014) \\
\hline Yun, et al. ${ }^{63}$ (2007) & Obradović, et al. ${ }^{75}$ (2011) & Raman, et al. ${ }^{86}(2014)$ \\
\hline O'Connell, et al..$^{54}$ (2008) & Cirano, et al. ${ }^{66}(2012)$ & Bezerra, et al. ${ }^{82}(2015)$ \\
\hline Llambes, et al. ${ }^{51}$ (2008) & Kapellas, et al. ${ }^{71}$ (2013) & Priyanka, et al. ${ }^{85}$ (2015) \\
\hline Santos, et al. ${ }^{58}(2009)$ & Santos, et al. ${ }^{79}(2013)$ & \\
\hline Al-Zahrani, et al. ${ }^{41}$ (2009) & Wehmeyer, et al. ${ }^{81}$ (2013) & \\
\hline Engebretson and Hey-Hadavi ${ }^{46}$ (2011) & Nassar, et al. ${ }^{74}(2014)$ & \\
\hline Gilowski, et al. ${ }^{47}(2012)$ & Saengtipbovorn, et al. ${ }^{78}(2014)$ & \\
\hline Santos, et al. ${ }^{59}(2012)$ & Cullinan, et al. ${ }^{68}(2015)$ & \\
\hline Pradeep, et al. ${ }^{56}(2013)$ & Jamieson, et al..$^{70}(2015)$ & \\
\hline Macedo, et al. ${ }^{52}(2014)$ & Gelato, et al. ${ }^{69}(2016)$ & \\
\hline Miranda, et al. ${ }^{53}(2014)$ & Ramos, et al. ${ }^{76}(2016)$ & \\
\hline Tsalikis, et al. ${ }^{62}(2014)$ & Cortelli, et al. ${ }^{67}(2017)$ & \\
\hline Castro Dos Santos, et al. ${ }^{43}$ (2016) & Sabatini, et al. ${ }^{77}$ (2017) & \\
\hline El-Sharkawy, et al. ${ }^{45}(2016)$ & Tsobgny-Tsague, et al. ${ }^{80}(2018)$ & \\
\hline \multicolumn{3}{|l|}{ Kumari, et al. ${ }^{49}(2016)$} \\
\hline \multicolumn{3}{|l|}{ Pradeep, et al. ${ }^{55}(2016)$} \\
\hline \multicolumn{3}{|l|}{ Tamashiro, et al..$^{61}$ (2016) } \\
\hline \multicolumn{3}{|l|}{ Al-Askar, et al. ${ }^{40}(2017)$} \\
\hline \multicolumn{3}{|l|}{ Demirturk-Gocgun, et al. ${ }^{44}$ (2017) } \\
\hline \multicolumn{3}{|l|}{ Lira Junior, et al..$^{50}(2017)$} \\
\hline \multicolumn{3}{|l|}{ Barbosa, et al. ${ }^{42}(2018)$} \\
\hline Zare Javid, et al. ${ }^{64}$ (2018) & & \\
\hline
\end{tabular}

Figure 3- Characteristics and names of the excluded studies $(n=49)$

Random sequence generation (selection bias)

Allocation concealment (selection bias)

Blinding of participants and personnel (performance bias)

Blinding of outcome assessment (detection bias)

Incomplete outcome data (attrition bias)

Selective reporting (reporting bias)

Other bias
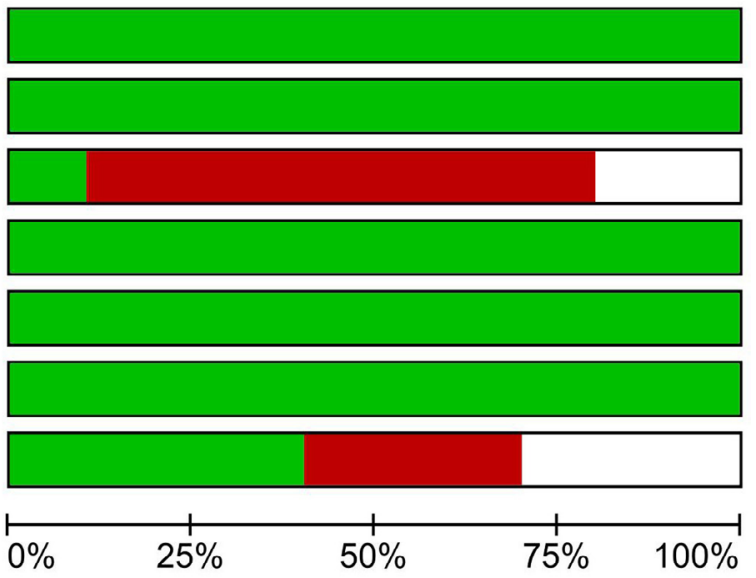

Low risk of bias

Unclear risk of bias

High risk of bias

Figure 4- Risk of bias graph: review author's judgment about each risk of bias item presented as percentages across all included studies of periodontal treatment on HbA1c levels does not bias. suggest the presence of publication biases (Figure 7). Regarding the studies included in the CRP metaanalysis, the limited study number does not allow a clear assessment of the absence of possible publication 


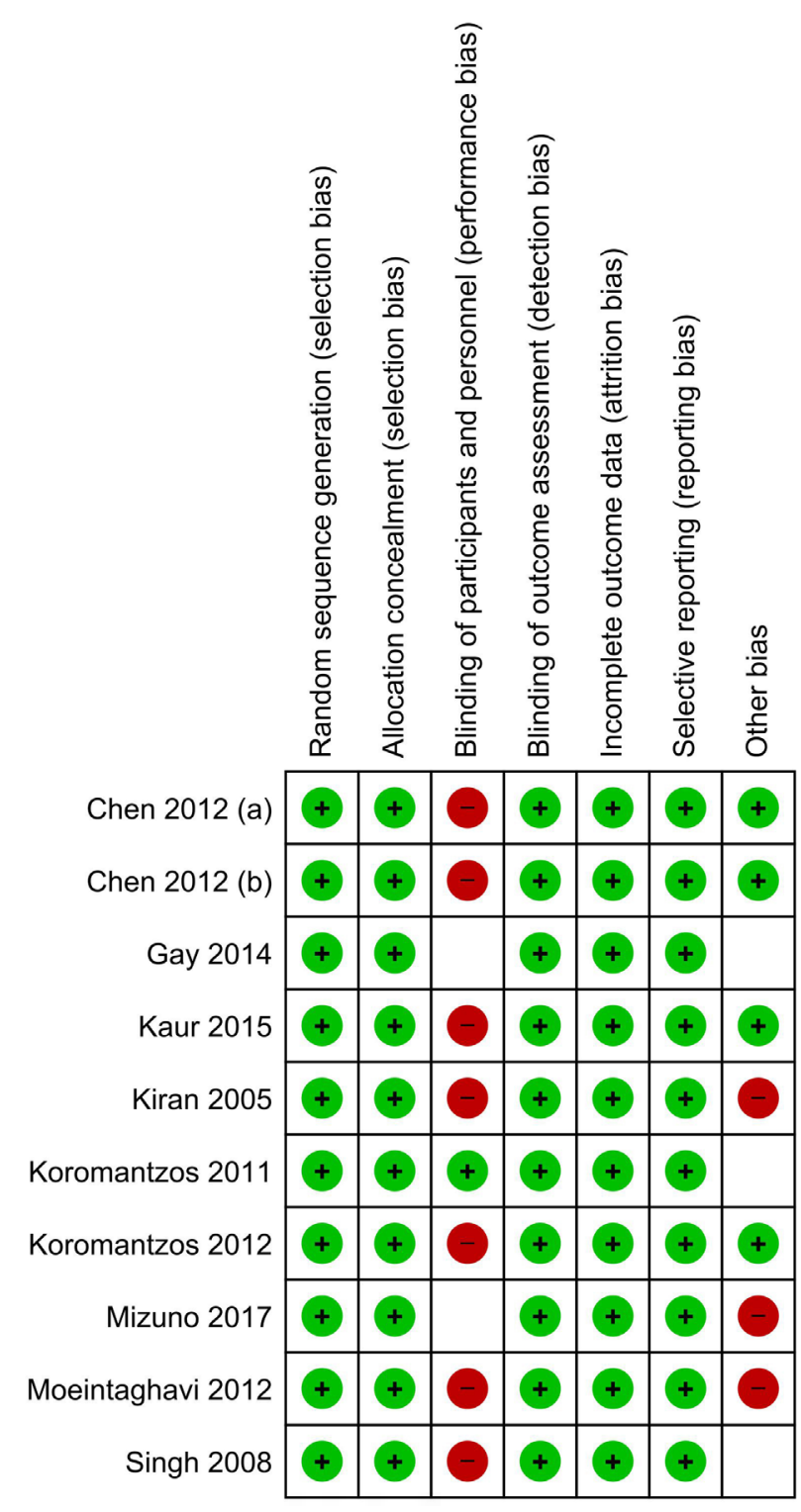

Figure 5- Risk of bias summary: review author's judgments about each risk of bias item for each included study

\section{Discussion}

The present systematic review with its two metaanalyses indicates that conventional periodontal treatment can improve metabolic control and reduce systemic inflammation in patients with T2D by reducing serum levels of $\mathrm{HbA} 1 \mathrm{c}$ and $\mathrm{CRP}$, respectively. The results of the metabolic control achieved by treatment and the reduction of systemic inflammation are consistent with the results of other systematic reviews and metaanalyses. ${ }^{88-90}$ However, in the present review, for the first time, the effect of the periodontal intervention on both outcome variables was evaluated simultaneously, with the same study methodology and inclusion criteria. Thus, this review used strict eligibility criteria, such as the presence of $\geq 3$ months of follow-up, which reflects the period in which the changes in $\mathrm{HbA} 1 \mathrm{c}$ and CRP are more stable and relevant. In addition, randomized studies comparable to each other were included, which strongly contributed to the reliability of the results.

The meta-analysis determining the overall effect of periodontal treatment on $\mathrm{HbA} 1 \mathrm{c}$ levels showed relative consistency between the studies included, an absence of heterogeneity $\left(\mathrm{I}^{2}=0 \%\right)$, and a significant effect in the intervention group $(p<0.01)$. These results, similar to those previously found, reinforce the hypothesis that suggests that periodontal treatment generates improved HbA1c levels in patients with T2D. The effect size, measured in terms of mean differences between the delta (initial-final) of the intervention group vs. control, showed an overall effect of $0.56 \%$ ( 0.36 0.75 ) at the end of the follow-up period. The clinical implications of achieving better metabolic control of diabetic patients are clearly established; specifically, the microvascular complications related to diabetes are reduced by $35 \%$ for each $1 \%$ decrease in $\mathrm{HbA} 1 \mathrm{c}$ levels. Additionally, an absolute decrease of $1 \%$ in the $\mathrm{HbA} 1 \mathrm{c}$ level can decrease the risk of any death related to diabetes by $21 \% .{ }^{17}$ Future studies are necessary to determine the direct impact of periodontal treatment on complications and the risk of dying associated with T2D.

Although these results $(0.56 \%)$ are consistent with previous studies, it is interesting to see that the overall effect found in this study considerably exceeds the $0.29 \% \mathrm{HbA} 1 \mathrm{c}$ reported by Simpson, et al. ${ }^{89}$ (2015). It is likely that the incorporation of studies subsequent to Simpson's review, such as the study by Kaur, et al.32 (2015), will favor the results of the present study. Another major explanation is that in the studies included in the present review the interventions were based on conventional periodontal treatment that included: oral hygiene instruction and SRP (with or without flap surgery) compared with the passive option (without periodontal treatment), these results were similar to those reported by Simpson, et al. ${ }^{89}$ (2015) with a reduction of $0.41 \% \mathrm{HbA} 1 \mathrm{c}$ when similar conditions were analyzed. However, when Simpson analyzed different interventions, for example, when incorporating antimicrobials or alternative periodontal treatments, the results were considerably lower ${ }^{89}$.

Regarding CRP levels, although the meta-analysis showed a significant overall effect with an absence of heterogeneity, this result must be evaluated with caution due to the small number of studies analyzed. However, the results are consistent with each other and with other studies ${ }^{88}$ that reflect the impact of 
A.

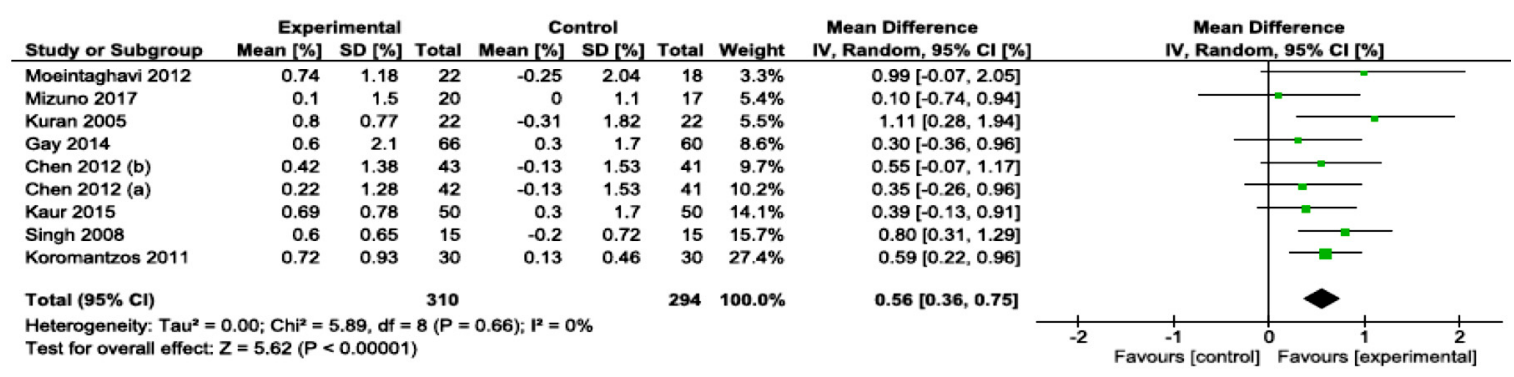

B.

\begin{tabular}{|c|c|c|c|c|c|c|c|c|c|c|}
\hline Study or Subgroup & \multicolumn{3}{|c|}{ Intervención } & \multicolumn{3}{|c|}{ Control } & \multicolumn{2}{|r|}{ Mean Difference } & \multicolumn{2}{|c|}{$\begin{array}{c}\text { Mean Difference } \\
\text { IV, Random, } 95 \% \mathrm{Cl}[\mathrm{mg} / \mathrm{I}\end{array}$} \\
\hline Chen 2012 (b) & 1.56 & 0.733 & 43 & -0.35 & 1.06 & 41 & $23.0 \%$ & $1.91[1.52,2.30]$ & & - \\
\hline Chen 2012 (a) & 1.63 & 0.715 & 42 & -0.35 & 1.06 & 41 & $23.2 \%$ & $1.98[1.59,2.37]$ & & - \\
\hline Koromantzos 2012 & 1.265 & 0.52 & 30 & -0.575 & 0.49 & 30 & $53.9 \%$ & $1.84[1.58,2.10]$ & & + \\
\hline Total $(95 \% \mathrm{Cl})$ & & & 115 & & & 112 & $100.0 \%$ & $1.89[1.70,2.08]$ & & $\bullet$ \\
\hline $\begin{array}{l}\text { Heterogeneity: Tau } \\
\text { Test for overall effect: }\end{array}$ & $\begin{array}{l}0.00 ; \text { Chi }^{2}=0.3 \\
Z=19.73\langle P<\end{array}$ & $\begin{array}{l}6, d f=2(P \\
0.00001)\end{array}$ & $=0.83$ & $=0 \%$ & & & & & $\begin{array}{c}-2 \\
\text { Favours [control] }\end{array}$ & ${ }^{1} \quad c \quad 2$ \\
\hline
\end{tabular}

Figure 6- Forest Plot of comparision: A. Periodontal therapy outcome: Change in $\mathrm{HbA} 1 \mathrm{c}(\% \mathrm{HbA} 1 \mathrm{c})$. B. Periodontal therapy outcome: Change in CRP

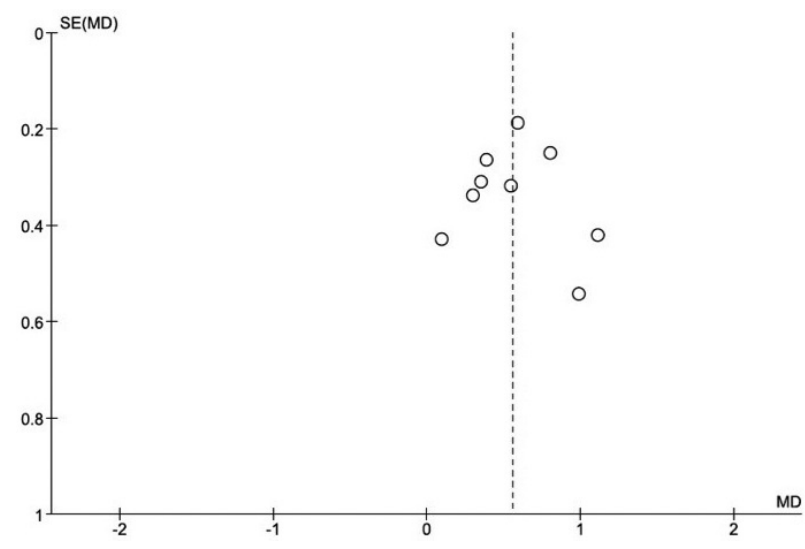

Figure 7- Funnel plot of comparision: Periodontal therapy outcome: Change in $\mathrm{HbA} 1 \mathrm{C}$

periodontal treatment at the marker-level of systemic inflammation. This result complements those found in previous systematic reviews in relation to the potential effects of periodontal treatment on the general health of patients with $T 2 D$, enhancing the hypothesis regarding a dual explanatory path for reducing systemic inflammation, namely, one path directly through the reduction of proinflammatory mediators such as TNF-alpha, IL-1, and IL-6, which induce acutephase responses with hepatic biosynthesis and elevated serum CRP levels, and another path indirectly through the reduction of $\mathrm{HbA} 1 \mathrm{c}$ itself as a result of the reduction of insulin resistance. In this case, the effect size was a mean difference of $1.89 \mathrm{mg} / \mathrm{l}$ [(1.70-2.08), $p<0.01]$. CRP is the most commonly used inflammatory marker in clinical practice, and its importance not only lies in its reliability but also, along with some other acutephase reactants, in its ability to be an active part of the pathogenic mechanism of atherosclerosis. ${ }^{91}$ Prospective studies show that increased CRP plasma concentrations of small magnitude, even within limits that were previously considered "normal" (below $10 \mathrm{mg} / \mathrm{L}$ ), predict acute cardiovascular events apart from other risk factors. ${ }^{92}$ Patients with T2D present an increase in systemic inflammation, which partly explains the considerable increase in cardiovascular risk. This increase in inflammation adds to the presence of chronic inflammatory processes such as periodontitis, which constitutes an additional source of systemic proinflammatory mediators, and could explain the even greater increase in cardiovascular risk.

The included studies considered different levels of severity and extent of periodontitis (moderate, moderate to advanced, severe) that could have an impact on the final outcome (systemic and local). More severe pathologies could generate a more significant change in the local and systemic inflammation of patients with T2D, which could partly explain some differences in the results. Similarly, the included studies presented differences in their criteria for selecting diabetic patients with different degrees of metabolic control. Increased changes in $\mathrm{HbA} 1 \mathrm{c}$ levels after periodontal treatment have been observed in patients with poor metabolic control and/or patients with acceptable or optimal control of HbA1c levels $(<7 \%) .32$ When stratifying by level of control, it was observed that the deltas (initial-final) in the periodontal intervention group were $1.49 \pm 0.98 \%$ in patients with poor control (HbA1c $<7 \%)$ and $0.16 \pm 0.32 \%$ in patients with good metabolic control. Quintero, et al. ${ }^{93}$ (2018) 
reported that periodontal treatment generated a greater impact in the reduction of $\mathrm{HbA} 1 \mathrm{c}$ in patients with levels $>9 \%(0.31 \%$ vs $0.88 \%) .{ }^{93}$ These aspects must be considered for future research and for an adequate interpretation of the results.

Regarding the excluded studies, 272 studies were excluded in a first phase of screening. Since this phase, differences have already been observed with Simpson's Cochrane review, ${ }^{89}$ which unlike ours includes patients with type 1 diabetes. Later in the eligibility stage, 48 complete articles were excluded due to inadequate control group $(n=25)$, inadequate intervention and/ or inadequate case definition $(n=17)$ and inadequate evaluation and/or high risks of bias $(n=6)$. There are clearly differences with the Simpson's review who uses different modalities of periodontal treatment (with the use of antimicrobials or new therapies) not included in the present review. Other articles such as Zhang, et al. ${ }^{87}$ (2013) or $\mathrm{Li}$, et al. ${ }^{84}$ (2011) for presenting an inadequate evaluation and high risks of bias were also excluded from the present review. This may explain why the Simpson's Cochrane review includes more articles $(n=35)$ and excludes less $(n=12)$ unlike our review that includes less $(n=9)$, and excludes more $(n=49)$. Our purpose was to be highly rigorous when including the studies for the present systematic review. More details of the characteristics and names of the excluded studies are presented in Figure 3.

The quality of evidence from a systematic review depends to a large extent on the quality of the included studies. In this case, the eligible study design was the randomized controlled clinical trial that, due to its lower risk of bias, represents the most appropriate design for assessing the efficacy of periodontal treatment. However, it is necessary to clarify that the type of study does not necessarily guarantee a good quality of evidence and that, therefore, clinical trials may also present biases that prevent the attainment of accurate results, invalidating our results. In this case, the included studies presented some risks of important biases that included performance bias due to the inherent nature of the design and the lack of an adequate placebo. Regarding other sources of bias, generally, the included studies are of good quality because they have low risks of systematic errors.

Another limitation of this study was the lack of a statistical analysis to evaluate the possibility of publication bias (such as the Egger test) that could support the funnel plot results. In addition, it should be noted that only two database sources were used for the bibliographic search; since other databases exist, it is important for future reviews to include additional sources of information. Finally, only English language literature was reviewed. Searching vernacular indexed literature might give more data for systematic review.

The high prevalence, morbidity and mortality of T2D explain why the management of the disease and its complications consume such a high percentage of the health budget of different countries. While in Chile it reaches $10.2 \%, 94$ in Mexico it exceeds $15 \%$ of the total health budget. In 2014, DM2 caused 4.9 million deaths and an expenditure of 612 billion dollars worldwide. ${ }^{95}$

The results of the present systematic review with its two meta-analyses reinforce and complement the evidence regarding the efficacy of periodontal treatment in the improvement of metabolic control and in the reduction of systemic inflammation of patients with T2D. In this context, the implication of incorporating periodontal treatment into the care of patients with T2D could constitute a policy of high impact for the public health of the country.

\section{Conclusion}

SRP has an impact on metabolic control and reduction of systemic inflammation of patients with T2D. Periodontal treatment could constitute an innovative therapeutic approach as a public health measure to reduce complications and improve the cardiovascular health of patients with T2D. Intervention and cost-effectiveness studies in the context of public health systems in different countries are necessary to evaluate the possible design of public policies in this area.

\section{Acknowledgments}

This study was supported by a grant provided by Federación Iberopanamericana de Periodoncia (FIPP) and FONDEF IDEA ID18I10034. We would like to thank Mr. Juan Fernandez from Language and Translation services of the Faculty of Dentistry, University of Chile for kindly correcting the English spelling and grammar of this study. The authors declare that there are no conflicts of interest. 


\section{References}

1- Genco R, Grossi S, Ho A, Nishimura F, Murayama Y. A proposed mode linking inflammation to obesity, diabetes, and periodontal infections. J Periodontol. 2005:76:2075-84

2- Saito T, Shimazaki Y. Metabolic disorders related to obesity and periodontal disease. Periodontol 2000. 2007:43:254-66.

3- Mathers C, Loncar D. Projections of global mortality and burden of disease from 2002 to 2030. PLoS Med. 2006:3:e442.

4- Pan American Health Organization - PAHO. Diabetes shows upward trend in the Americas [Internet]. 2012. [cited 2018 Aug 29]. Available from: https://www.paho.org/hq/index.php?option=com_co ntent\&view $=$ article\&id $=7460: 2012$-diabetes-shows-upward-trendamericas\&Itemid $=4327 \&$ lang $=$ pt.

5- Chile. Ministerio de Salud. Encuesta Nacional de Salud 2016/2017 [Internet]. 2017. [cited 2018 Aug 29]. Available from: http://www. ipsuss.cl/ipsuss/site/artic/20171122/asocfile/20171122142253/ ens_2016_17_primeros_resultados.pdf.

6- Gamonal J, Mendoza C, Espinoza I, Muñoz A, Urzúa I, Aranda W, et al. Clinical attachment loss in Chilean adult population: first Chilean National Dental Examination Survey. J Periodontol. 2010:81:1403-10. 7- Duque A. Prevalencia de periodontitis crónica en Iberoamérica. Rev Clin Periodoncia Implant Rehabil Oral. 2016:9:208-15.

8- Chavarry N, Vettore M, Sansone C, Sheiham A. The relationship between diabetes mellitus and destructive periodontal disease: a meta-analysis. Oral Heal Prev Dent. 2009:7:107-27.

9- Kumar V, Fausto N, Abbas A, Cotran R, Robbins S. Robbins and Cotran pathologic basis of disease. Philadelphia: Saunders; 2005.

10- Bascones-Martínez A, Muñoz-Corcuera M, Bascones-Ilundain J. Diabetes and periodontitis: a bidirectional relationship. Med Clin (Barc). 2015:145:31-5

11- Taylor G, Burt B, Becker M, Genco R, Shlossman M, Knowler W, et al. Severe periodontitis and risk for poor glycemic control in patients with non-insulin-dependent diabetes mellitus. J Periodontol. 1996:67 Suppl 10S:1085-93.

12- Acharya A, Thakur S, Muddapur M, Kulkarni R. Systemic cytokines in type 2 diabetes mellitus and chronic periodontitis. Curr Diabetes Rev. 2018:14:182-8.

13- Mesia R, Gholami F, Huang H, Clare-Salzler M, Aukhil I, Wallet $S$, et al. Systemic inflammatory responses in patients with type 2 diabetes with chronic periodontitis. BMJ Open Diabetes Res Care. 2016:4:e000260.

14- Southerland JH, Taylor GW, Moss K, Beck JD, Offenbacher S. Commonality in chronic inflammatory diseases: periodontitis, diabetes, and coronary artery disease. Periodontol 2000. 2006:40:130-43.

15- Schmidt A, Yan S, Brett J, Mora R, Nowygrod R, Stern D. Regulation of human mononuclear phagocyte migration by cell surfacebinding proteins for advanced glycation end products. J Clin Invest. 1993:91:2155-68

16- Steel $D$, Whitehead $A$. The major acute phase reactants: C-reactive protein, serum amyloid $\mathrm{P}$ component and serum amyloid $\mathrm{A}$ protein. Immunol Today. 1994:15:81-8.

17- Selvin E, Steffes M, Zhu H, Matsushita K, Wagenknecht L, Pankow J, et al. Glycated hemoglobin, diabetes, and cardiovascular risk in nondiabetic adults. N Engl J Med. 2010:362:800-11.

18- Fernandez-Real J, Ricart W. Insulin resistance and chronic cardiovascular inflammatory syndrome. Endocr Rev. 2003:24:278-301. 19- Manzur F, Alvear C, Alayón AN. Role of C-reactive protein in cardiovascular diseases. Rev Colomb Cardiol. 2011:18:273-8.

20- Jialal I, Devaraj S, Venugopal S. C-reactive protein: risk marker or mediator in atherothrombosis? Hypertension. 2004:44:6-11.

21- Paraskevas S, Huizinga J, Loos B. A systematic review and metaanalyses on $\mathrm{C}$-reactive protein in relation to periodontitis. J Clin Periodontol. 2008:35:277-90.
22- Torrungruang K, Katudat D, Mahanonda R, Sritara P, Udomsak A. Periodontitis is associated with elevated serum levels of cardiac biomarkers - soluble ST2 and C-reactive protein. J Clin Periodontol. 2019:46;809-18

23- Hasuike A, Iguchi S, Suzuki D, Kawano E, Sato S. Systematic review and assessment of systematic reviews examining the effect of periodontal treatment on glycemic control in patients with diabetes. Med Oral Patol Oral Cir Bucal. 2017:22:e167-76.

24- Landis J, Koch G. The measurement of observer agreement for categorical data. Biometrics. 1977:33:159-74.

25- Landis J, Koch G. An application of hierarchical kappa-type statistics in the assessment of majority agreement among multiple observers. Biometrics. 1977:33:363-74.

26- Higgins J, Altman D, Gøtzsche $P$, Jüni $P$, Moher D, Oxman A, et al. The Cochrane Collaboration's tool for assessing risk of bias in randomised trials. BMJ. 2011:343:d5928.

27- World Health Organization - WHO. Definition and diagnosis of diabetes mellitus and intermediate hyperglycaemia [Internet]. Geneva: WHO; 2016. [cited 2018 Aug 29]. Available from: http://whqlibdoc. who.int/publications/2006/9241594934_eng.pdf.

28- DerSimonian R, Laird N. Meta-analysis in clinical trials. Control Clin Trials. 1986:7:177-88.

29- Sterne J, Egger M. Funnel plots for detecting bias in meta-analysis: guidelines on choice of axis. J Clin Epidemiol. 2001:54:1046-55.

30- Chen L, Luo G, Xuan D, Wei B, Liu F, Li J, et al. Effects of nonsurgical periodontal treatment on clinical response, serum inflammatory parameters, and metabolic control in patients with type 2 diabetes: a randomized study. J Periodontol. 2012:83:435-43.

31- Gay I, Tran D, Cavender A, Weltman R, Chang J, Luckenbach E, et al. The effect of periodontal therapy on glycaemic control in a Hispanic population with type 2 diabetes: a randomized controlled trial. J Clin Periodontol. 2014:41:673-80.

32- Kaur P, Narula S, Rajput R, K Sharma R, Tewari S. Periodontal and glycemic effects of nonsurgical periodontal therapy in patients with type 2 diabetes stratified by baseline HbA1c. J Oral Sci. 2015:57:201-11. 33- Kiran M, Arpak N, Ünsal E, Erdoğan M. The effect of improved periodontal health on metabolic control in type 2 diabetes mellitus. J Clin Periodontol. 2005:32:266-72

34- Koromantzos P, Makrilakis K, Dereka X, Katsilambros N, Vrotsos I, Madianos P. A randomized, controlled trial on the effect of nonsurgical periodontal therapy in patients with type 2 diabetes. Part I: effect on periodontal status and glycaemic control. J Clin Periodontol. 2011:38:142-7

35- Koromantzos P, Makrilakis K, Dereka X, Offenbacher S, Katsilambros $\mathrm{N}$, Vrotsos I, et al. Effect of non-surgical periodontal therapy on $\mathrm{C}$-reactive protein, oxidative stress, and matrix metalloproteinase (MMP)-9 and MMP-2 levels in patients with type 2 diabetes: a randomized controlled study. J Periodontol. 2012:83:3-10.

36- Mizuno H, Ekuni D, Maruyama T, Kataoka K, Yoneda T, Fukuhara $D$, et al. The effects of non-surgical periodontal treatment on glycemic control, oxidative stress balance and quality of life in patients with type 2 diabetes: a randomized clinical trial. PLoS One. 2017:12;e0188171.

37- Moeintaghavi A, Arab HR, Bozorgnia Y, Kianoush K, Alizadeh M. Non-surgical periodontal therapy affects metabolic control in diabetics: a randomized controlled clinical trial. Aust Dent J. 2012:57:31-7. 38- Singh S, Kumar V, Kumar S, Subbappa A. The effect of periodontal therapy on the improvement of glycemic control in patients with type 2 diabetes mellitus: a randomized controlled clinical trial. Int J Diabetes Dev Ctries. 2008:28(2):38-44.

39- Eke P, Page R, Wei L, Thornton-Evans G, Genco R. Update of the case definitions for population-based surveillance of periodontitis. J Periodontol. 2012:83:1449-54. 
40- Al-Askar M, Al-Kheraif A, Ahmed H, Kellesarian S, Malmstrom $H$, Javed $F$. Effectiveness of mechanical debridement with and without adjunct antimicrobial photodynamic therapy in the treatment of periodontal inflammation among patients with prediabetes. Photodiagnosis Photodyn Ther. 2017:20:91-4.

41- Al-Zahrani M, Bamshmous S, Alhassani A, Al-Sherbini M. Short-term effects of photodynamic therapy on periodontal status and glycemic control of patients with diabetes. J Periodontol. 2009:80:1568-73.

42- Barbosa F, Araújo P, Machado L, Magalhães C, Guimarães M, Moreira A. Effect of photodynamic therapy as an adjuvant to nonsurgical periodontal therapy: periodontal and metabolic evaluation in patients with type 2 diabetes mellitus. Photodiagnosis Photodyn Ther 2018:22:245-50.

43- Castro Dos Santos N, Andere N, Araujo C, Marco A, Santos L, Jardini $M$, et al. Local adjunct effect of antimicrobial photodynamic therapy for the treatment of chronic periodontitis in type 2 diabetics: split-mouth double-blind randomized controlled clinical trial. Lasers Med Sci. 2016:31:1633-40.

44- Demirturk-Gocgun O, Baser U, Aykol-Sahin G, Dinccag N, Issever $\mathrm{H}$, Yalcin $\mathrm{F}$. Role of low-level laser therapy as an adjunct to initial periodontal treatment in type 2 diabetic patients: a splitmouth, randomized, controlled clinical trial. Photomed Laser Surg. 2017:35:111-5.

45- El-Sharkawy H, Anees M, Van Dyke T. Propolis improves periodontal status and glycemic control in patients with type 2 diabetes mellitus and chronic periodontitis: a randomized clinical trial. J Periodontol. 2016:87:1418-26

46- Engebretson S, Hey-Hadavi J. Sub-antimicrobial doxycycline for periodontitis reduces hemoglobin $\mathrm{A} 1 \mathrm{C}$ in subjects with type 2 diabetes: a pilot study. Pharmacol Res. 2011:64:624-9.

47- Gilowski L, Kondzielnik P, Wiench R, Plocica I, Strojek K, Krzeminski T. Efficacy of short-term adjunctive subantimicrobial dose doxycycline in diabetic patients-randomized study. Oral Dis. 2012:18:763-70.

48- Grossi S, Skrepcinski F, DeCaro T, Robertson D, Ho A, Dunford R, et al. Treatment of periodontal disease in diabetics reduces glycated hemoglobin. J Periodontol. 1997:68:713-9.

49- Kumari M, Martande S, Pradeep A, Naik S. Efficacy of subgingivally delivered $1.2 \%$ atorvastatin in the treatment of chronic periodontitis in patients with type 2 diabetes mellitus: a randomized controlled clinical trial. J Periodontol. 2016:87:1278-85.

50- Lira Junior R, Santos C, Oliveira B, Fischer R, Santos A. Effects on $\mathrm{HbA} 1 \mathrm{c}$ in diabetic patients of adjunctive use of systemic antibiotics in nonsurgical periodontal treatment: a systematic review. J Dent. 2017:66:1-7.

51- Llambés F, Silvestre F, Hernández-Mijares A, Guiha R, Caffesse $R$. The effect of periodontal treatment on metabolic control of type 1 diabetes mellitus. Clin Oral Investig. 2008:4:337-43.

52- Macedo GO, Novaes AJ, Souza S, Taba MJ, Palioto D, Grisi M. Additional effects of a PDT on nonsurgical periodontal treatment with doxycycline in type II diabetes: a randomized, controlled clinical trial. Lasers Med Sci. 2014:29:881-6.

53- Miranda T, Feres M, Perez-Chaparro P, Faveri M, Figueiredo L, Tamashiro $\mathrm{N}$, et al. Metronidazole and amoxicillin as adjuncts to scaling and root planing for the treatment of type 2 diabetic subjects with periodontitis: 1-year outcomes of a randomized placebo-controlled clinical trial. J Clin Periodontol. 2014:41:890-9.

54- O'Connell P, Taba M, Nomizo A, Foss Freitas M, Suaid F, Uyemura $\mathrm{SA}$, et al. Effects of periodontal therapy on glycemic control and inflammatory markers. J Periodontol. 2008:79:774-83.

55- Pradeep A, Garg V, Raju A, Singh P. Adjunctive local delivery of Aloe vera gel in patients with type 2 diabetes and chronic periodontitis: a randomized, controlled clinical trial. J Periodontol. 2016:87:268-74.
56- Pradeep A, Rao N, Bajaj P, Kumari M. Efficacy of subgingivally delivered simvastatin in the treatment of patients with type 2 diabetes and chronic periodontitis: a randomized double-masked controlled clinical trial. J Periodontol. 2013:84:24-31.

57- Rodrigues D, Taba MJ, Novaes A, Souza S, Grisi M. Effect of nonsurgical periodontal therapy on glycemic control in patients with type 2 diabetes mellitus. J Periodontol. 2003:74:1361-7.

58- Santos V, Lima J, Mendonça A, Maximo M, Faveri M, Duarte P. Effectiveness of full-mouth and partial-mouth scaling and root planing in treating chronic periodontitis in subjects with type 2 diabetes. ] Periodontol. 2009:80:1237-45.

59- Santos V, Ribeiro F, Lima J, Miranda T, Feres M, Bastos M, et al. Partial- and full-mouth scaling and root planing in type 2 diabetic subjects: a 12-mo follow-up of clinical parameters and levels of cytokines and osteoclastogenesis-related factors. J Periodontal Res. 2012:47:45-54

60- Skaleric U, Schara R, Medvescek M, Hanlon A, Doherty F, Lessem J. Periodontal treatment by Arestin and its effects on glycemic control in type 1 diabetes patients. J Int Acad Periodontol. 2004:6:160-5. 61- Tamashiro N, Duarte P, Miranda T, Maciel S, Figueiredo L, Faveri $M$, et al. Amoxicillin plus metronidazole therapy for patients with periodontitis and type 2 diabetes: a 2-year randomized controlled trial. J Dent Res. 2016:95:829-36.

62- Tsalikis L, Sakellari D, Dagalis P, Boura P, Konstantinidis A. Effects of doxycycline on clinical, microbiological and immunological parameters in well-controlled diabetes type-2 patients with periodontal disease: a randomized, controlled clinical trial. J Clin Periodontol. 2014:41:972-80. 63- Yun F, Firkova E, Jun-Qi L, Xun H. Effect of non-surgical periodontal therapy on patients with type 2 diabetes mellitus. Folia Med (Plovdiv). 2007:49:32-6.

64- Zare Javid A, Maghsoumi-Norouzabad L, Ashrafzadeh E, Yousefimanesh $\mathrm{H}$, Zakerkish $\mathrm{M}$, Ahmadi Angali $\mathrm{K}$, et al. Impact of cranberry juice enriched with omega-3 fatty acids adjunct with nonsurgical periodontal treatment on metabolic control and periodontal status in type 2 patients with diabetes with periodontal disease. J Am Coll Nutr. 2018:37:71-9.

65- Calabrese N, D'Aiuto F, Calabrese A, Patel K, Calabrese G, MassiBenedetti $M$. Effects of periodontal therapy on glucose management in people with diabetes mellitus. Diabetes Metab. 2011:37:456-9.

66- Cirano F, Pera C, Ueda P, Casarin R, Ribeiro F, Pimentel S, et al. Clinical and metabolic evaluation of one-stage, full-mouth, ultrasonic debridement as a therapeutic approach for uncontrolled type 2 diabetic patients with periodontitis. Quintessence Int. 2012:43:671-81.

67- Cortelli S, Costa F, Gargioni-Filho A, Aquino D, Cota L, Scherma A, et al. Impact of gingivitis treatment for diabetic patients on quality of life related to periodontal objective parameters: a randomized controlled clinical trial. Arch Oral Biol. 2018:86:80-6.

68- Cullinan M, Palmer J, Faddy M, Westerman B, Carle A, West M, et al. The influence of triclosan on biomarkers of cardiovascular risk in patients in the cardiovascular and periodontal study (CAPS): a randomized controlled trial. J Periodontol. 2015:86:847-55.

69- Gelato M, Schoenfeld E, Hou W, Michalowicz B, Seaquist E, Oates T, et al. Changes in diabetes medications in the Diabetes and Periodontal Therapy Trial and their effect on hemoglobin A1c (HbA1c). Contemp Clin Trials. 2016:50:21-7.

70- Jamieson L, Skilton M, Maple-Brown L, Kapellas K, Askie L, Hughes J, et al. Periodontal disease and chronic kidney disease among Aboriginal adults; an RCT. BMC Nephrol. 2015:16:181.

71- Kapellas K, Do L, Bartold P, Skilton M, Maple-Brown L, O'Dea $K$, et al. Effects of full-mouth scaling on the periodontal health of Indigenous Australians: a randomized controlled trial. J Clin Periodontol. 2013:40:1016-24. 
72- Khader Y, Al Habashneh R, Al Malalheh M, Bataineh A. The effect of full-mouth tooth extraction on glycemic control among patients with type 2 diabetes requiring extraction of all remaining teeth: a randomized clinical trial. J Periodontal Res. 2010:45:741-7.

73- Nassar C, Moraes R, Secundes M, Bernardon P, Nassar P, Camilotti $V$. The effect of resin composites and polishing procedure on periodontal tissue parameters in patients with diabetes mellitus. Eur J Prosthodont Restor Dent. 2014:22:146-51.

74- Nassar C, Serraglio A, Balotin A, Colet D, Camilotti V, Busato $P M$, et al. Effect of maintenance therapy with or without the use of chlorhexidine in teeth restored with composite resin in patients with diabetes mellitus. Gen Dent. 2011:59:e149-52.

75- Obradović R, Kesić L, Jovanović G, Petrović D, Goran R, Mihailović D. Low power laser efficacy in the therapy of inflamed gingive in diabetics with parodontopathy. Vojnosanit Pregl. 2011:68:684-9.

76- Ramos U, Ayub L, Reino D, Grisi M, Taba M Jr, Souza S, et al. Antimicrobial photodynamic therapy as an alternative to systemic antibiotics: results from a double-blind, randomized, placebocontrolled, clinical study on type 2 diabetics. J Clin Periodontol. 2016:43:147-55.

77- Sabatini S, Lauritano D, Candotto V, Silvestre F, Nardi G. Oral probiotics in the management of gingivitis in diabetic patients: a double blinded randomized controlled study. J Biol Regul Homeost Agents. 2017:31(2 Suppl 1):197-202.

78- Saengtipbovorn S, Taneepanichskul S. Effectiveness of lifestyle change plus dental care ( $L C D C$ ) program on improving glycemic and periodontal status in the elderly with type 2 diabetes. BMC Oral Health. 2014:14:72.

79- Santos V, Lima J, Miranda T, Gonçalves T, Figueiredo L, Faveri M, et al. Full-mouth disinfection as a therapeutic protocol for type-2 diabetic subjects with chronic periodontitis: twelve-month clinical outcomes: a randomized controlled clinical trial. J Clin Periodontol. 2013:40:155-62. 80- Tsobgny-Tsague NF, Lontchi-Yimagou E, Nana AR, Tankeu AT, Katte JC, Dehayem MY, et al. Effects of nonsurgical periodontal treatment on glycated haemoglobin on type 2 diabetes patients (PARODIA 1 study): a randomized controlled trial in a sub-Saharan Africa population. BMC Oral Health. 2018:18:28.

81- Wehmeyer M, Kshirsagar A, Barros S, Beck J, Moss K, Preisser J, et al. A randomized controlled trial of intensive periodontal therapy on metabolic and inflammatory markers in patients with ESRD: results of an exploratory study. Am J Kidney Dis. 2013:61:450-8.

82- Bezerra JP, Shaddox LM, Mendonça AC, Bastos MF, Miranda TS, Santos VR, et al. Local levels of biomarkers after surgical and nonsurgical debridement of residual pockets and nonresidual sites in diabetic patients: a 12-month follow-up. Gen Dent. 2015:63:58-64. 83- Hincapié J, Castrillón C, Yepes F, Roldan N, Becerra M, Moreno S, et al. Microbiological effects of periodontal therapy plus azithromycin in patients with diabetes: results from a randomized clinical trial. Acta Odontol Latinoam. 2014:27:89-95.
84- Li Z, Sha Y, Zhang B, Zhu L, Kang J. Effect of community periodontal care intervention on periodontal health and glycemic control in type 2 diabetic patients with chronic periodontitis. Beijing Da Xue Xue Bao Yi Xue Ban. 2011:43:285-9.

85- Priyanka N, Kalra N, Saquib S, Malgaonkar N, Tarakji B, Varsha J, et al. Efficacy of subgingivally delivered satranidazole in the treatment of type 2 diabetes subjects with chronic periodontitis: a randomized controlled clinical trial. J Int Acad Periodontol. 2015:17:42-8.

86- Raman R, Taiyeb-Ali T, Chan S, Chinna K, Vaithilingam R. Effect of nonsurgical periodontal therapy verses oral hygiene instructions on type 2 diabetes subjects with chronic periodontitis: a randomised clinical trial. BMC Oral Health. 2014:14:79.

87- Zhang H, Li C, Shang S, Luo Z. Scaling and root planing with enhanced root planing on healthcare for type 2 diabetes mellitus: a randomized controlled clinical trial. J Dent Sci. 2013:8:272-80.

88- Artese H, Foz A, Rabelo MS, Gomes G, Orlandi M, Suvan J, et al. Periodontal therapy and systemic inflammation in type 2 diabetes mellitus: a meta-analysis. PLoS One. 2015;10(5):e0128344.

89- Simpson T, Weldon J, Worthington H, Needleman I, Wild S, Moles $D$, et al. Treatment of periodontal disease for glycaemic control in people with diabetes mellitus. Cochrane Database Syst Rev. 2015:11:CD004714.

90- Teshome A. The efficacy of chlorhexidine gel in the prevention of alveolar osteitis after mandibular third molar extraction: a systematic review and meta-analysis. BMC Oral Health. 2017:17:82.

91- Nelson R, Shlossman M, Budding L, Pettitt D, Saad M, Genco R, et al. Periodontal disease and NIDDM in Pima Indians. Diabetes Care. 1990:13:836-40.

92- Hackam D, Anand S. Emerging risk factors for atherosclerotic vascular disease: a critical review of the evidence. JAMA. 2003:290:93240.

93- Quintero AJ, Chaparro A, Quirynen M, Ramirez V, Prieto D, Morales $\mathrm{H}$, et al. Effect of two periodontal treatment modalities in patients with uncontrolled type 2 diabetes mellitus: a randomized clinical trial. J Clin Periodontol. 2018:45:1098-106.

94- World Health Organization - WHO. Global Health Expenditure Database [online]. Geneva: WHO; 2015. [cited 2018 Aug 29]. Available from: https://apps.who.int/nha/database.

95- Federación Mexicana de Diabetes. Gasta Salud 15 porciento de su presupuesto en atención a la diabetes [Internet]. 2015. [cited 2018 Aug 29]. Available from: http://fmdiabetes.org/presupuesto-atenciondiabetes-gasta-15-presupuesto-salud/. 